\section{WHY AUDITORS AND PUBLIC COMPANIES NEED INTERNATIONAL REGULATION}

The corporate scandals and misconduct at major US corporations have exposed major weaknesses in the legal and regulatory standards of corporate governance in the United States. Financial mismanagement and fraudulent earnings misstatements at major public companies, such as Enron, WorldCom, Tyco, Adelphia and a host of other companies have wiped away hundreds of billions of \$US from the value of investment funds. The global operations of many of these corporations have also put other economies at risk, and in particular foreign investors who have become major investors in US companies in recent years, with the result that corporate and auditor wrongdoing in the US will result in great losses for many non-US investors who put great faith in the accuracy of US company reports. Indeed, the call for a new system of audit regulation and tougher penalties for corporate wrongdoing can be heard not only in the US, but also in other important financial markets.

In the US, efforts at auditor and corporate reform have been spearheaded by Paul Sarbanes, Democratic Senator from Maryland and Chairman of the Senate Banking Committee, whose first proposals last May for auditor reform and increased penalties for corporate wrongdoing met with stiff resistance from the accounting lobbyists and the Bush administration. But when WorldCom admitted to a $\$ 3.9$ billion accounting fraud, the public outcry was overwhelming with the result that the Sarbanes Bill passed the Senate unanimously. Throughout the summer this Bill was posed against a weaker alternative proposed in the House of Representatives by Michael Oxley, the Republican Chairman of the House Committee on Financial Services. Although the final Bill that passed both Houses of Congress on 26 July 2002 contained some proposals of the Oxley bill, it was clear that the Sarbanes Bill's tougher provisions had prevailed.

The Bill's harshest provisions covering accounting reform impose an outright ban for accountants on performing nine kinds of audit service that include building and managing financial information systems, investment banking, and legal services. Accountants that seek to perform non-audit work that falls outside these categories must first obtain approval by the company's audit committee. The Bill's proponents, however, considered and rejected a proposal to require audit firms to rotate their clients every few years. In Britain, this proposal has received much stronger support by the UK Government in its recent White Paper on Company Law Reform.

The US Bill also requires the establishment of a new government accounting board to review the audits of public companies. The board will have broad investigatory powers with the authority to impose civil and criminal sanctions against auditors who fail to discharge their duties

\section{Articles}

Lions or squeaking mice?

The Pinochet precedent and the 'Garzón effect': on catalysts, contestation and loose ends

Conclusions of the SALS working party on welfare choices for incapacitated adults

The effects of the Human Rights Act 1998 on arbitration

24

Public-private partnership agreements in Romania

News 16

to provide independent and accurate assessments of the financial health of public companies. The new board will be taxpayer funded and its members will be appointed by the Securities and Exchange Commission, and thus independent of the accounting profession. Moreover, the Oxley and Sarbanes Bills proposed tough civil and criminal penalties to punish the executives of public companies who wilfully fail to adhere to provisions requiring them to certify the accuracy and truthfulness of company accounts. The final Bill contains penalties that can result in 20-year prison sentences for senior executives and directors who wilfully breach certain reporting requirements.

In addition, the extraterritorial provisions of the final Bill extend jurisdiction of the new board to foreign accounting firms who advise and prepare accounting reports for public companies listed in the US. Indeed, extraterritoriality has been a major feature of most important US economic and financial regulation for the last 30 years and will continue to be so under the new law. The issue of extraterritoriality however raises the broader issue of whether other countries should adopt similar measures to reform the accounting industry and the regulation of public companies. In Britain, the UK government is also attempting to strengthen corporate governance standards and improve financial reporting for publicly-listed companies.

Despite these national efforts at reform, this will not be enough to stem efforts by companies, such as Tyco and its disgraced chairman Dennis Koslowski, to establish themselves in offshore jurisdictions like Bermuda, where many US companies have recently established themselves to avoid and evade US corporate tax and regulatory requirements. An international solution is required, and this could possibly take place at the Organisation for Economic Cooperation and Development where its international convention on corporate governance standards could be reformed to require all OECD states to adhere to minimum standards of financial reporting for publicly listed companies and to adopt codes of practice for auditors who advise them.

\section{Dr Kern Alexander}

Butterworths Senior Research Fellow,

International Financial Regulation, and

Postgraduate Tutor in Law, IALS 